\author{
ALEKSANDRA SZYMAŃSKA \\ ORCID: 0000-0003-0569-3005 \\ Uniwersytet Wrocławski \\ Instytut Historii Państwa i Prawa \\ Zakład Prawa Rzymskiego
}

\title{
CONSILIA A INNE GATUNKI LITERATURY PRAWNICZEJ
}

\begin{abstract}
Abstrakt: Najogólniej rzecz ujmując, consilium nazywano poradę prawną, będącą w swej istocie analizą określonego problemu prawnego, sporządzaną w języku łacińskim w średniowieczu i w epokach następnych, najczęściej przez mających uniwersyteckie przygotowanie jurystów. Celem artykułu jest przedstawienie consilium w kontekście innych gatunków literackich, w ramach których juryści związani ze szkołami glosatorów i komentatorów formułowali swoje refleksje nad prawem.
\end{abstract}

Słowa kluczowe: consilia, komentarz, glosatorzy, komentatorzy

\section{WPROWADZENIE}

Od czasu, kiedy zaczęły istnieć pierwsze fakultety prawa, począwszy od założenia Uniwersytetu Bolońskiego, tradycyjnie datowanego na 1088 rok, związani z nimi uczeni stworzyli wiele gatunków literatury prawniczej. Ich powstanie miało związek z egzegezą autorytatywnych tekstów, za które uważali kompilację justyniańską i święte kanony. Szkoła glosatorów (około 1100-1260) koncentrowała swoje wysiłki na interpretowaniu prawa justyniańskiego za pomocą rozmaitego typu glos, które były notatkami umieszczanymi między wierszami lub na marginesach tekstu, łączonych następnie w aparaty. Pewne innowacje wprowadzili, stosując bardziej swobodne podejście do interpretacji tekstu, akademiccy juryści ze szkoły orleańskiej. Na ich metodach oparli się prawnicy ze szkoły komentatorów, zwani także postglosatorami (około 1260-1500), rozwijając i modyfikując gatunki tworzone przez poprzedników, jak również wprowadzając własne. Jednym z takich gatunków literatury prawniczej, którego znaczenie dla badań nad ewolucją prawa cywilnego jest nie do przecenienia, było consilium — porada prawna ${ }^{1}$. Ce-

${ }^{1} \mathrm{Na}$ temat consilia powstała bogata literatura; zob. m.in. W. Engelmann, Die Wiedergeburt der Rechtskultur in Italien durch die wissenschaftliche Lehre, Leipzig 1938; G. Rossi, Consilium 
lem artykułu jest przedstawienie consilium w kontekście innych gatunków literackich, w ramach których juryści związani ze szkołami glosatorów i komentatorów formułowali swoje refleksje nad prawem.

Wraz z rozwojem w średniowieczu włoskich miast i komplikowaniem się stosunków społeczno-gospodarczych wzrosło zapotrzebowanie na regulacje prawne, częściowo zaspokajane przez lokalne prawo statutowe. Bywało ono jednak niekompletne i niespójne. Pełniejszym, choć pochodzącym z innej epoki, systemem prawnym było studiowane na uniwersytetach prawo justyniańskie. Biegli w nim juryści za jego pomocą rozwiązywali za jego pomocą wiele problemów praktycznych, a efekty tych rozwiązań prezentowali w consilia. Najogólniej rzecz ujmując, consilium nazywano poradę prawną, będącą w swej istocie analizą określonego problemu prawnego, sporządzaną w języku łacińskim w średniowieczu i w epokach następnych najczęściej przez mających uniwersyteckie przygotowanie jurystów. Chociaż porady prawne na zamówienie różnych podmiotów sporządzali prawnicy o różnym zakresie wykształcenia akademickiego, największą popularność i ponadczasowość zyskały consilia sporządzane przez nauczycieli akademickich. Profesorowie dzielili swój czas przeznaczony na pracę zawodową pomiędzy zajęcia akademickie a angażowanie się w życie społeczno-polityczne miasta, w tym także w wymiar sprawiedliwości. W tym ostatnim zakresie oczekiwano od nich fachowych opinii prawnych. Zamawiającym mógł być każdy, kto chciał ustalić pewną sytuację prawną, a zatem strony, ale także ten, komu przyszło rozstrzygać spór. Uczeni ci w naturalny sposób byli najbardziej predestynowani do tego zajęcia, nie tylko dlatego, że przez wiele lat studiowali prawo, a później objaśniali jego literę studentom, ale także dlatego, że często uczestniczyli w jego powstawaniu, pracując nad redagowaniem czy rewizją statutów miejskich. Mieli zatem głęboką wiedzę o prawie i potrafili argumentować rozstrzygnięcia.

Poszczególne consilia miały praktyczny cel i w założeniu nie stanowily literatury prawniczej. Zamawiano je i sporządzano, aby ustalić stan prawny lub

sapientis iudiciale. Studi e ricerche per la storia del processo romano-canonico, Milano 1958; L. Lombardi, Saggio sul diritto giurisprudenziale, Milano 1967; M. Ascheri, Rechtsprechungs und Konsiliensammlungen, [w:] Handbuch der Quellen und Literatur der Neueren europäischen Privatrechtsgeschichte, II. 2, red. H. Coing, München 1976, s. 1113-1121; M. Ascheri, I consilia dei giuristi medievali: per un repertorio-incipitario computerizzato, Siena 1982; Consilia im späten Mittelalter: Zum historischen Aussagewert einer Quellengattung, red. I. Baumgartner, Sigmaringen 1995; Legal Consulting in the Civil law Tradition, red. M. Ascheri, I. Baumgärtner, J. Kirshner, Berkeley 1999; M. Ascheri, I consilia dei giuristi: una fonte per il tardo Medioevo, „Bullettino dell'Istituto storico italiano per il Medioevo" 2003, nr 105; Consilium, Teorie e pratiche del consigliare nella cultura medievale, red. C. Casagrande, C. Crisciani, S. Vecchio, Firenze 2004; R. Wojciechowski, Średniowieczne consilia prawnicze, „Przegląd Prawa i Administracji” 59, 2004, s. 169-176; G. Murano, I consilia giuridici dalla tradizione manoscritta alla stampa, „Reti Medievali Rivista 15, 2014, nr 1; U. Falk, Consilia. Studien zur Praxis der Rechtsgutachten in der frühen Neuzeit, Frankfurt a. M 2006; W. Druwé, Loans and Credit in Consilia and Decisiones in the Low Countries (c. 1500-1680), Boston 2019, s. 33-52. 
pozyskać argumenty w sporze, po wykorzystaniu zaś były składane ad acta. Ich właściwości jednak spowodowały, że z czasem stały się niezwykle popularnym gatunkiem literatury prawniczej.

\section{JAK CONSILIA STAŁY SIĘ GATUNKIEM LITERACKIM?}

Jak już zostało wskazane, consilia mogły być zamawiane przez różne podmioty. Historycznie pierwsze są porady sporządzane dla sędziów, czyli tak zwane consilium sapientis iudiciale - o nich też, dzięki przeprowadzonym badaniom, wiemy najwięcej. Początkowo wkład uczonych w rozstrzyganie sporów sądowych miał zapewne spontaniczny charakter, kiedy to sędzia zwracał się do jurysty z prośbą o opinię na temat toczącej się sprawy. Systematyczny udział doktorów prawa w postępowaniach sądowych miał miejsce w szczególności, gdy sędzią był podesta, nieposiadający — jako cudzoziemiec — znajomości prawa statutowego komuny, w której rozstrzygał, ani też prawa rzymskiego. Był on jednak odpowiedzialny za swoje wyroki, z których mógł być rozliczony po zakończeniu kadencji w ramach procedury zwanej sindicato ${ }^{2}$. Zwracał się więc po pomoc prawną do uczonego prawnika, na którego opinii opierał swój wyrok. Tego typu porada zamawiana przez sędziego u uczonego prawnika zwana była consilium sapientis iudiciale. Należy zaznaczyć, że nawet gdy wyrok był wiernym odzwierciedleniem porady prawnej, formalnie były to akty odrębne. Często taka konsultacja była konieczna na mocy prawa statutowego. W XII-XIII wieku juryści udzielali porad prawnych sędziemu lub urzędnikom najczęściej ustnie ${ }^{3}$. Zachowały się jednak przykłady spisanych consilia autorstwa Azona, Accursiusa czy Johannesa Bassianusa. Podczas gdy u progu XIII wieku ten typ był już dobrze ugruntowany, drugi typ, czyli consilia przeznaczone dla klientów indywidualnych, jeszcze przez całe to stulecie nie był w powszechnym użyciu. Consilia dla stron zwane były pro veritate. Były to porady szczególnego rodzaju, zamawiane wprawdzie przez strony, ale z definicji mające wskazywać obiektywny stan rzeczy. Zamawiająca je strona musiała liczyć się z tym, że rozstrzygnięcie może być dla niej niekorzystne.

Metoda sporządzania consilia zależała od podmiotów kierujących pytanie i od osób, które miały na nie udzielać odpowiedzi. Mogły być one zamawiane i udzielane w różnych formach. Zapytania spisywano na pergaminie bądź też wpisywano je do specjalnych rejestrów zakładanych i prowadzonych przez jurystę właśnie w tym celu. Czasami pytania przychodziły drogą listowną. Odpowiadając na nie, juryści stosowali analogiczną formę — zapisywali consilium na tej samej

\footnotetext{
2 G. Rossi, op. cit., s. 43.

3 Ibidem, s. 78.
} 
karcie, na której zostało sformułowane pytanie, wpisywali odpowiedź do rejestru lub też odpowiadali na list z prośbą o rozstrzygnięcie sprawy ${ }^{4}$.

Consilia mogą być definiowane jako gatunek literacki od momentu, gdy juryści zaczęli je gromadzić i wykorzystywać w oderwaniu od konkretnych sporów, na potrzeby których powstały. Ich autorzy przechowywali consilia między innymi dlatego, aby mieć już gotowe argumenty prawne, które mogły być wykorzystywane w przyszłych sprawach. Takie consilia, z których często usuwano indywidualizujące je szczegóły, wskazujące na osoby czy miejsca, były następnie rozpowszechniane i używane do rozwiązywania innych podobnych przypadków ${ }^{5}$. W ten sposób powstawały zbiory porad prawnych jednego lub kilku autorów wydawane pod nazwą Consilia lub Responsa, w których umieszczano consilia różnego typu, zarówno wydawane na zamówienie sędziów, jak i pro veritate. Czasami dodawano tam teoretyczne rozstrzygnięcia problemów prawnych, które w istocie nie zostały opracowane na podstawie żadnej konkretnej sprawy. Powstawanie takich zbiorów było spowodowane zainteresowaniem, jakim cieszyły się opinie uczonych jurystów u praktyków prawa $\mathrm{z}$ uwagi na zawarty tam sposób rozumowania zmierzający do rozstrzygnięcia oraz konkretne przemawiające za nim argumenty. Zaczęły więc odgrywać inną rolę niż ta, dla której zostały pierwotnie napisane, stając się nieocenioną pomocą dla osób związanych z wymiarem sprawiedliwości. Jako gatunek literatury prawniczej consilia stały się popularne w XIV wieku i utrzymywały swoją popularność w wieku następnym.

Fenomen i popularność consilia polega na tym, że znajdowały zastosowanie nie tylko w sprawach, dla których powstawały. Jak to określił R. Wojciechowski, po tym, jak zostały wykorzystane w konkretnym przypadku, ,zaczynały swój byt niezależny ${ }^{6}$. Praktyczne znaczenie gatunku wiąże się z liczbą i znaczeniem zbiorów, w które ujmowano consilia. Bardzo wielu prawników sporządzało konsylia na zamówienie określonych podmiotów i wiele spośród owych porad prawnych zostało później ujętych w zbiory, choć stosunkowo rzadko przez ich autorów. Prawdopodobnie pierwszym zbiorem consilia rozpowszechnianym w manuskryptach był zbiór Dinusa Mugellanusa, który jest także jednym z najstarszych zbiorów drukowanych ${ }^{7}$. Niestety jego wybitny uczeń Cynus de Pistoia nie połączył swych porad w uporządkowany zbiór. Również Bartolus de Saxoferrato nie zdążył za życia zebrać swych porad prawnych w zbiór. Uczynili to po jego śmierci jego bliscy. Baldus de Ubaldis zgromadził konsylia w porządku chronologicznym, wciągając do swego zbioru nawet te, których autorami byli inni juryści. Niektóre

4 Tak M. Bellomo, Common Legal Past of Europe, Washington D. C. 1995, s. 169-170.

5 Zob. J. Kirshner, Consilia as authority in late medieval Italy: The case of Florence, [w:] Legal Consulting in the Civil law Tradition, red. M. Ascheri, I. Baumgärtner, J. Kirshner, Berkeley 1999, s. 117.

${ }^{6}$ R. Wojciechowski, op. cit., s. 174.

7 G. Murano, op. cit., s. 254. 
zbiory zawierały porady kilku autorów. Rewolucyjne znaczenie dla rozpowszechniania consilia miał druk.

\section{CONSILIA A TWÓRCZOŚĆ GLOSATORÓW}

Pierwsze consilia powstawały jeszcze w ramach działalności szkoły glosatorów. Podstawową metodą było sporządzanie glos, które mogły być prostym objaśnieniem słów, czasem różnych ich wariantów lub też dokładniejszą interpretacją treści glosowanego fragmentu. Analizując fragment, glosatorzy zaznaczali także odniesienia do innych części kompilacji justyniańskiej, tworząc system alegacji. W ich mniemaniu, zgodnie z tym, co zostało zapisane w De confirmatione digestorum (O zatwierdzeniu Digestów), system powinien być spójny i dlatego należało rozwiązać wszelkie sprzeczności ${ }^{8}$. Porządkując materiał zawarty w różnych częściach Corpus iuris civilis, ustalali tym samym pewne reguły ogólne. Aby dociec, która $\mathrm{z}$ reguł powinna mieć zastosowanie, zbierali argumenty na ich rzecz (pro) oraz przeciwko nim (contra). Waga tych argumentów decydowała o tym, co było regułą, a co wyjątkiem od niej. Wszystkie te operacje skutkowały powstaniem takich gatunków literackich, jak brocarda, dissensiones dominorum, distinctiones ${ }^{9}$.

Gatunki te miały ścisły związek z nauczaniem uniwersyteckim - tworząc je, profesorowie przygotowywali się do zajęć. Zapisem wygłaszanych przez nich wykładów była zaś lectura. Podczas tak zwanych repetitiones (odbywających się popołudniami) poprzez pogłębioną dyskusję kontynuowano rozważania nad danymi fragmentami ${ }^{10}$. Jako gatunek literacki repetitio upowszechnił się w obrębie szkoły orleańskiej ${ }^{11}$. Studenci analizowali problemy i argumentowali swoje sta-

8 Constitutio Tanta $\S 15$ : „Contrarium autem aliquid in hoc codice positum nullum sibi locum vindicabit nec invenitur, si quis subtili animo diversitatis rationes excutiet: sed est aliquid novum inventum vel occulte positum, quod dissonantiae querellam dissoluit et aliam naturam inducit discordiae fines effugientem”. „W tym zbiorze praw żadne sprzeczne ze sobą regulacje nie będą ubiegać się o miejsce dla siebie ani żadne nie zostaną znalezione jeśli tylko zbada się z wnikliwym nastawieniem umysłu powody wystąpienia różnic miedzy nimi. Odkrywa się wtedy bowiem coś nowo wprowadzonego albo o ukrytym znaczeniu, co usuwa zarzut braku zgodności i nadaje sprawie odmienny aspekt, przenosząc ją poza obszar sprzeczności”. Digesta Iustiniani - Digesta Justyniańskie. Tekst i przektad, t. 1, ks. 1-4, red. T. Palmirski, Kraków 2013, s. 149.

9 Zob. P. Weimar, Die legistische Literatur der Glossatorenzeit, [w:] Handbuch der Quellen und Literatur der neueren europaischen Privatrechtsgeschichte, t. 1. Mittelalter (1100-1500), Die gelehrten Rechte und die Gesetzgebung, red. H. Coing, München 1973, s. 129-260.

${ }^{10}$ R. Wojciechowski, Zwiazek dydaktyki uniwersyteckiej i form literatury naukowej w XII i XIII wieku, „Prawo. Studia Historycznoprawne” 303, 2007, s. 182-183.

11 C.H. Bezemer, Les répétitions de Jacques de Révigny: recherches sur la répétition comme forme d'enseignement juridique et comme genre littéraire, suivies d'un inventaire des textes, Leiden 1987.

Przegląd Prawa i Administracji CXX, 2020, cz. 1 i 2

(C) for this edition by CNS 
nowiska podczas tak zwanych dysput, których spisywanie dało początek innemu rodzajowi literatury prawniczej, czyli quaestiones disputatae ${ }^{12}$.

Kolejnym gatunkiem literatury prawniczej tworzonym przez glosatorów jest summa będąca całościowym opracowaniem poszczególnych tytułów Corpus iuris. Charakteryzuje się ona pewnym porządkiem streszczania fragmentów w ramach tytułu $^{13}$. W tym czasie powstawała również literatura na temat prawa procesowego — ordines iudiciarii — dająca opis postępowania sądowego. Jednym z najważniejszych dzieł tego rodzaju jest Speculum iudiciale Guilelmusa Durandusa.

Ustalenia poczynione podczas studiów nad prawem rzymskim i podczas tworzenia wskazanych gatunków literatury prawniczej były uwzględniane w consilia sporządzanych zarówno przez glosatorów, jak i przez ich sukcesorów komentatorów. Za pomocą technik interpretacji i argumentacji wypracowanych przez glosatorów rozwiązywano tam pojawiające się problemy prawne.

Wielu glosatorów, oprócz działalności dydaktycznej i związanej z nią twórczości literackiej pracowało jako doradcy prawni dla różnych podmiotów, w tym dla władców. Dla przykładu cesarz Frederick Barbarossa zatrudniał doktorów bolońskich w charakterze doradców w sprawach, w których był skonfliktowany z miastami włoskimi ${ }^{14}$. Autorami najstarszych znanych nam consilia są Johannes Basianus ${ }^{15}$ oraz $\mathrm{Azo}^{16}$ (około 1150-1225). Porady prawne tworzyli także Odofredus (około 1200-1265) oraz Accursius ${ }^{17}$.

\section{CONSILIA A QUAESTIONES}

Norbert Horn, dokonując przeglądu literatury tworzonej w czasach komentatorów, zaliczył quaestiones i consilia do jednej grupy, którą określił jako „Entsche-

12 Zob. B.C. Bazàn et al., Les question disputées et les questions quodlibétiques dans les facultés de Théologie, de Droit et de Médecine, Turnhout1985.

13 Zob. R. Wojciechowski, Związek dydaktyki uniwersyteckiej..., s. 180-181.

14 J. Baszkiewicz, Omnia sunt principia. O własności i jurysdykcji w koncepcji politycznej glosatorów i postglosatorów (XII-XIV w.), „Zeszyty Naukowe Uniwersytetu Wrocławskiego. Seria A" 1961, nr 34, s. 57 n.

15 E. Meijers, Les Glossateurs Et Le Droit Féodal, „Tijdschrift voor Rechtsgeschiedenis / Revue d'Histoire du Droit / The Legal History Review" 13, 1934, nr 2, s. 129-149; A. Belloni, Giovanni Bassiano Consulente, „Ius Commune” 1994, nr 21, s. 78-148.

16 L. Chiapelli, L. Zdekauer, Un consulto d'Azzone dell'anno 1205 ora per la prima volta pubblicato, Pistoia 1888.

17 Zob. H. Lange, Römisches Recht im Mittelalter, t. 1. Die Glossatoren, München 1997, s. 333; H. Dendorp, E. J. H Schrage, The sources of medieval learned law, [w:] Creation of the Ius Commune: From Casus to Regula, red. J.W. Cairns, P.J. de Plessis, Edinburgh 2010, s. 29; M. Bellomo, Consulenze professionali e dottrine di professori. Un inedito 'consilium domini Accursii', „Quaderni catanesi di studi classici e medievali” 1982, nr 7, s. 199-219. 
idungsliteratur" 18 , w skład której wchodzą prace zawierające odpowiedzi dotyczące konkretnego przypadku prawnego. Quaestiones disputatae ściśle łączyły się z pracą nauczycieli prawa i stanowiły odpowiedź na hipotetyczne pytania stawiane w ramach procesu dydaktycznego. Tematów do nich często dostarczały właśnie consilia. Dzięki podobnej strukturze consilium można było łatwo przekształcić $\mathrm{w}$ quaestio $^{19}$. Studenci mieli zatem możliwość zetknięcia się z realnymi przypadkami, które występowały w praktyce prawnej. Jednocześnie jeżeli problem został rozpatrzony $\mathrm{w}$ jednej z quaestio, stanowiła ona podstawę dla consilium, które zostało zamówione w analogicznej, lecz rzeczywistej sprawie. Ta wzajemna zależność jest przejawem wymiany doświadczeń pomiędzy uniwersytetem a salą sądową ${ }^{20}$.

Zarówno w quaestiones, jak i w typowych consilia na początku znajduje się krótki opis faktów (factum, thema, casus lub epitome) ${ }^{21}$. Dalej pada pytanie lub też seria pytań. Ponieważ quaestiones w założeniu były ćwiczeniami na argumentowanie możliwych rozstrzygnięć, owe argumenty za i przeciw (pro et contra) starannie w nich przedstawiano. Na koniec podawano rozwiązanie (solutio), osobisty pogląd autora wraz z przytoczeniem argumentów na jego poparcie przedstawionymi już wcześniej albo też zupełnie nowymi. Z kolei w najprostszych consilia uwzględniona została jedynie odpowiedź na pytanie, bez uzasadnienia. W rozwiniętej ich formie odpowiedź na zadane pytanie opiera się na argumentach, zwykle przytaczane i odrzucane są również argumenty przeciwne. Argumenty, które prowadzą do akceptowanego przez autora rozwiązania (solutio), są często omawiane bardzo szczegółowo. Można tutaj dostrzec różnicę w stosunku do quaestio disputata, w której więcej uwagi poświęca się odrzucaniu kontrargumentów ${ }^{22}$. Często jednak ostateczna odpowiedź jest udzielana na pytanie, które jest uzasadnione szeregiem argumentów, brakuje wówczas argumentów contra ${ }^{23}$. Różnicą formalną, która pozwala odróżnić quaestiones od consilia, jest to, że te pierwsze nie były opatrzone pieczęciami ani nie posiadały subscriptio. Ponieważ w zbiorach consilia znajdują się jednak także przypadki hipotetyczne, granica między tymi gatunkami nie była wcale tak wyraźna, jak można by oczekiwać.

18 N. Horn, Die Legistiche Literatur der Kommentatoren und der Ausbreitung des gelehrten Rechts, [w:] Handbuch der Quellen..., s. 315.

19 E. Cortese, Il rinascimento giuridico medievale, Roma 1996, s. 71.

20 P.R. Pazzaglini, C.A Hawks, Consilia a Bibliography of Holdings in the Library of Congress and Certain Other Collections in the United States, Washington 1990.

${ }^{21}$ H. Lange, M. Kriechbaum, Römisches Recht im Mittelalter, t. 2. Die Kommentatoren, München 2007, s. 399.

22 Ibidem.

23 W. Engelmann, op. cit., s. 305; H. Lange, M. Kriechbaum, op. cit., s. 399-400. 


\section{CONSILIA A KOMENTARZE}

Za koniec epoki glosatorów uznaje się opracowanie przez Accursiusa († 1263) Glossa ordinaria, będącej aparatem do całego Corpus iuris civilis, ułożonym na podstawie wieloletnich studiów nad prawem prowadzonych w szkole bolońskiej przez różnych mistrzów. Odtąd to właśnie do tego dzieła i zawartych tam interpretacji będą się odnosić kolejni doktorzy prawa. Uczeni ci, będący kontynuatorami szkoły glosatorów, zwani są komentatorami — podobnie jak glosatorzy — od podstawowej metody badań, a jednocześnie ulubionej formy ich twórczości (komentarza), lub też właśnie konsyliatorami ${ }^{24}$, ponieważ ten gatunek literatury prawniczej był równie często przez nich wykorzystywany. Komentatorzy jako sukcesorzy glosatorów posługiwali się i rozwijali stosowane przez nich metody prowadzenia badań nad tekstem, a także bazowali na ich rozstrzygnięciach, najczęściej powołując się właśnie na Glossę Accursiusa, która stanowiła podsumowanie osiągnięć glosatorów ${ }^{25}$.

Komentatorzy analizowali tekst źródłowy według pewnego schematu, a poszczególne fazy tejże analizy znajdowały odzwierciedlenie w literackiej formie, jaką był komentarz. Był on znacznie bardziej rozbudowaną formą interpretacji tekstu niż glosy, zebrane nawet w największe i najbardziej rozbudowane aparaty. Komentarz otwierało zazwyczaj summarium, zwane także dictum, czyli krótkie streszczenie danego fragmentu, ogólna informacja o tym, czego dotyczy mający być komentowanym fragment. W continuatio objaśniano fragment w kontekście fragmentów z nim sąsiadujących. W divisio - według określonego kryterium dzielono fragment na pewne części, z których każdą następnie analizowano. Aby uczynić analizę bardziej zrozumiałą, dodawano praktyczny przykład - casus, w którym omawiana norma znajdowała zastosowanie. Niektóre komentarze zawierały tak zwane expositio textus, czyli objaśnianie fragmentu z odniesieniami do konkretnych słów komentowanego tekstu. W notabilia uwzględniano różnego typu spostrzeżenia, które nasuwały się podczas lektury tekstu, wyprowadzone $\mathrm{z}$ niego reguły ogólne czy powiązane z nim fragmenty. W disputatio formułowano tezę (positio) i antytezę (oppositio), a następnie podawano rozwiązanie, które było obroną tezy (responsio). W ten sposób, po rozwiązaniu wszelkich pojawiających się sprzeczności, osiągano pewne ustalenie (determinatio). Czasem rozwiązanie było uzależnione od przyjęcia dodatkowych warunków czy założeń, a zatem zawierało pewne distinctio. Uczeni w swoich komentarzach formułowali też quaestiones, czyli różnego typu pytania prawne. Należy zaznaczyć, że nie wszystkie elementy

${ }^{24}$ F. Wieacker, Privatrechtsgeschichte der Neuzeit, Göttingen 1967, s. 80 n.

25 Zob. A. Szymańska, Glossa ordinaria jako podsumowanie osiagnięć glosatorów, [w:] Okresy przejściowe: ustrój i prawo, red. J. Przygodzki, Wrocław 2019, s. 13-24; eadem, O znaczeniu Accursiusa i jego Glossa magna, „Rocznik Stowarzyszenia Naukowców Polaków Litwy” 2019, nr 19, s. 273-292. 
składowe w danym komentarzu występują jednocześnie i że poszczególni autorzy mogli tworzyć swoje indywidualne schematy ${ }^{26}$.

Podobnie jak w przypadku komentarza, sporządzanie consilia rządziło się pewną metodą, również uwzględniającą dialektyczne rozumowanie, inną jednak z uwagi na odmienny cel. Centralną częścią consilium są argumenty pro i contra poparte alegacjami do prawa rzymskiego i kanonicznego, zwyczajów i statutów komun włoskich, odwołaniami do Glossa Magna Accursiusa, a także opiniami innych jurystów, którzy komentowali odpowiednie tytuły właśnie w komentarzach lub badali podobne przypadki w swoich consilia.

Zarówno komentarze, jak i consilia były gatunkami często pisywanymi przez uczonych ze szkoły komentatorów. Komentowanie tekstów do celów akademickich przygotowywało uczonych do najbardziej wymagającej formy, jaką było rozstrzyganie konkretnych, niejednokrotnie bardzo skomplikowanych problemów prawnych i udzielanie porad różnym podmiotom. Opinie prawne zawarte w consilia często różniły się od prawa prezentowanego na wykładach uniwersyteckich. Podczas gdy zajęcia opierały się na ogólnie przyjętej, tradycyjnej doktrynie prawnej, autorzy consilia, w celu obrony interesów klientów, mogli się od niej odchylać27. Jednocześnie można spotkać się z poglądem, że consilia nawet wyparły komentarz jako źródło poglądów naukowych. Wśród powodów przedkładania w tym zakresie porad prawnych nad komentarz wymienia się to, że opinie w nich wyrażane są znacznie bardziej wyważone, gdyż ich autorzy nie chcieli narazić klientów na straty, a samych siebie na niesławę. W salach wykładowych, gdzie rozważania miały teoretyczny charakter, uczeni mieli o wiele większą swobodę w formułowaniu myśli. Ponadto opinie prawne rodzące się z konkretnych problemów prawnych miały bardziej realny charakter ${ }^{28}$. To wszystko sprawiło, że zapotrzebowanie na ten gatunek literatury prawniczej było ogromne. Popularność tego gatunku literackiego spowodowała, że zbiory porad prawnych wydawali także prawnicy mniej wybitni albo zupełnie przeciętni, a to z kolei doprowadziło do upadku gatunku ${ }^{29}$.

Poszczególni komentatorzy uprawiali oba te gatunki literackie. Żyjący jedynie 43 lata Bartolus de Saxoferrato napisał komentarze do wszystkich części Digestów, Kodeksu, Instytucji a także do Noweli justyniańskich. Udzielał również porad prawnych, które zostały zebrane w zbiór. Jego najwybitniejszy uczeń Baldus de Ubaldis, słynący ze znajomości zarówno prawa cywilnego, jak i kanonicznego, napisał komentarze do wszystkich części Corpus iuris civilis, a także udzielił wielu porad prawnych zebranych następnie w pięciu tomach. Oba te gatunki uprawiali także

26 N. Horn, op. cit., s. 323-326; H. Lange, M. Kriechbaum, op. cit., s. 363-364.

${ }^{27} \mathrm{M}$. Ascheri, Il consilium dei giuristi medievali, [w:] Consilium. Teorie e pratiche del consigliare nella cultura medievale, red. C. Casagrande, C. Crisciani, S. Vecchio, Firenze 2004, s. 243-258.

28 Ch. Valsecchi, Storia del diritto medievale e moderno, s. 69, http://www00.unibg.it/dati/corsi/19020/57030-Storia\%20del\%20diritto-corso\%202013-prima\%20parte.pdf (dostęp: 16.02.2020).

29 Ibidem, s. 70. 
Paulus de Castro, Alexander Tartagnus, Jason de Mayno i wielu innych. Wszyscy oni napisali monumentalne komentarze i wydali sporą liczbę consilia.

Szczytowy rozwój tych gatunków przypada na XIV/XV wiek, a i w wieku następnym z powodzeniem kontynuowano charakterystyczne dla nich metody rozumowania i schematy spisywania. Uważa się jednak, że powtarzanie tych samych wzorców było jedną z przyczyn, dla których gatunki te przestały się rozwijać, pomimo wyraźnego wzrostu liczby pisywanych dzieł. Przyszłość stała przed inną formą, jaką był traktat.

\section{ZAKOŃCZENIE}

Consilia łączą w sobie cechy literatury o charakterze zarówno teoretycznym, jak i praktycznym. W życiu prawno-politycznym trzynastowiecznej Italii za sprawą rozmaitych czynników nastąpił wzrost znaczenia doktorów prawa poza działalnością typowo akademicką. Przejawiało się to głównie na dwóch płaszczyznach - legislacyjnej, poprzez opracowywanie prawa statutowego, oraz procesowej, poprzez sporządzanie porad prawnych (consilia) na zamówienie sędziów. Taki stan rzeczy sprzyjał oddziaływaniu doktryny na praktykę i odwrotnie. W następnym stuleciu zaangażowanie uczonych jurystów w praktykę prawniczą stało się jeszcze większe, kiedy na szerszą skalę zaczęli udzielać porad prawnych także stronom procesowym.

Odnowienie studiów nad prawem rzymskim i działalność uczonych jurystów miała wpływ na powstanie gatunku literatury prawniczej, jakim są consilia. Pierwsze z nich sporządzane były przez prawników ze szkoły glosatorów, ale to w czasach ich następców, komentatorów, stały się jednym z najważniejszych, oprócz komentarza, gatunków literackich praktykowanych przez uczonych jurystów. W działalności literackiej przedstawicieli obu szkół można dostrzec wyraźną ciągłość, a na poszczególnych etapach ich naukowej ewolucji pojawiają się kolejne gatunki literackie nawiązujące do poprzednich i czerpiące z nich wzorce. Tak więc consilia noszą w sobie świadectwa glos, distinctiones, aparatów, summ, brocarda, quaestiones czy komentarzy.

\section{CONSILIA AMONG OTHER GENRES OF LEGAL LITERATURE}

\section{Summary}

Generally speaking, the consilium is legal advice, which is primarily an analysis of a specific legal problem, drafted in Latin during the Middle Ages and in subsequent centuries by university-trained lawyers. The aim of the paper is to describe the consilium in the context of other legal literary genres used by jurists connected with schools of glossators and commentators to formulate their reflections on the law.

Keywords: consilia, commentary, glossators, commentators 


\section{BIBLIOGRAFIA}

Ascheri M., I consilia dei giuristi medievali: per un repertorio-incipitario computerizzato, Siena 1982.

Ascheri M., I consilia dei giuristi: una fonte per il tardo Medioevo, „Bullettino dell'Istituto storico italiano per il Medioevo" 2003, nr 105.

Ascheri M., Il consilium dei giuristi medievali, [w:] Consilium. Teorie e pratiche del consigliare nella cultura medievale, red. C. Casagrande, C. Crisciani, S. Vecchio, Firenze 2004.

Ascheri M., Rechtsprechungs - und Konsiliensammlungen, [w:] Handbuch der Quellen und Literatur der Neueren europäischen Privatrechtsgeschichte, t. 2, red. H. Coing, München 1976.

Baszkiewicz J., Omnia sunt principia. O własności i jurysdykcji w koncepcji politycznej glosatorów i postglosatorów (XII-XIV w.), „Zeszyty Naukowe Uniwersytetu Wrocławskiego. Seria A”, 1961, nr 34.

Bazàn B.C., Wippel J.W., Fransen G., Jacquart D., Les question disputées et les questions quodlibétiques dans les facultés de Théologie, de Droit et de Médecine, Turnhout 1985.

Bellomo M., Common Legal Past of Europe, Washington D.C. 1995.

Bellomo M., Consulenze professionali e dottrine di professori. Un inedito 'consilium domini Accursii', „Quaderni catanesi di studi classici e medievali” 1982, nr 7.

Belloni A., Giovanni Bassiano Consulente, „Ius Commune” 1994, nr 21.

Bezemer C.H., Les répétitions de Jacques de Révigny: recherches sur la répétition comme forme d'enseignement juridique et comme genre littéraire, suivies d'un inventaire des textes, Leiden 1987.

Chiapelli L., Zdekauer L., Un consulto d'Azzone dell'anno 1205 ora per la prima volta pubblicato, Pistoia 1888.

Consilia im späten Mittelalter: Zum historischen Aussagewert einer Quellengattung, red. I. Baumgartner, Sigmaringen 1995.

Consilium. Teorie e pratiche del consigliare nella cultura medievale, red. C. Casagrande, C. Crisciani, S. Vecchio, Firenze 2004.

Cortese E., Il rinascimento giuridico medievale, Roma 1996.

Dendorp H., Schrage E.J.H, The sources of medieval learned law, [w:] Creation of the Ius Commune: From Casus to Regula: From Casus to Regula, red. J.W. Cairns, P.J. de Plessis, Edinburgh 2010.

Digesta Iustiniani - Digesta Justyniańskie. Tekst i przekład, t. 1, ks. 1-4, red. T. Palmirski, Kraków 2013.

Druwé W., Loans and Credit in Consilia and Decisiones in the Low Countries (c. 1500-1680), Boston 2019.

Engelmann W., Die Wiedergeburt der Rechtskultur in Italien durch die wissenschaftliche Lehre, Leipzig 1938.

Falk U., Consilia. Studien zur Praxis der Rechtsgutachten in der frühen Neuzeit, Frankfurt a. M. 2006.

Horn N., Die Legistiche Literatur der Kommentatoren und der Ausbreitung des gelehrten Rechts, [w:] Handbuch der Quellen und Literatur der neueren europäischen Privatrechtsgeschichte, t. 1. Mittelalter (1100-1500). Die gelehrten Rechte und die Gesetzgebung, red. H. Coing, München 1973.

Kirshner J., Consilia as authority in late medieval Italy: The case of Florence, [w:] Legal Consulting in the Civil law Tradition, red. M. Ascheri, I. Baumgärtner, J. Kirshner, Berkeley 1999.

Lange H., Kriechbaum M., Römisches Recht im Mittelalter, t. 2. Die Kommentatoren, München 2007.

Lange H., Römisches Recht im Mittelalter, t. 1. Die Glossatoren, München 1997.

Legal Consulting in the Civil law Tradition, red. M. Ascheri, I. Baumgärtner, J. Kirshner, Berkeley 1999. 
Lombardi L., Saggio sul diritto giurisprudenziale, Milano 1967.

Meijers E., Les Glossateurs Et Le Droit Féodal, „Tijdschrift voor Rechtsgeschiedenis / Revue d'Histoire du Droit / The Legal History Review" 13, 1934, nr 2.

Murano G., I consilia giuridici dalla tradizione manoscritta alla stampa, „Reti Medievali Rivista” 15, 2014, nr 1.

Pazzaglini P.R., Hawks C.A., Consilia a bibliography of holdings in the Library of Congress and Certain Other Collections in the United States, Washington 1990.

Rossi G., Consilium sapientis iudiciale. Studi e ricerche per la storia del processo romano-canonico, Milano 1958.

Szymańska A., Glossa ordinaria jako podsumowanie osiagnięć glosatorów, [w:] Okresy przejściowe: ustrój i prawo, red. J. Przygodzki, Wrocław 2019.

Szymańska A., O znaczeniu Accursiusa i jego Glossa magna, „Rocznik Stowarzyszenia Naukowców Polaków Litwy" 2019, nr 19.

Valsecchi Ch., Storia del diritto medievale e moderno, s. 69, http://www00.unibg.it/dati/corsi/19020/ 57030-Storia\%20del\%20diritto-corso\%202013-prima\%20parte.pdf (dostęp: 16.02.2020).

Weimar P., Die legistische Literatur der Glossatorenzeit, [w:] Handbuch der Quellen und Literatur der neueren europaischen Privatrechtsgeschichte, t. 1. Mittelalter (1100-1500), Die gelehrten Rechte und die Gesetzgebung, red. H. Coing, München 1973.

Wieacker F., Privatrechtsgeschichte der Neuzeit, Göttingen 1967.

Wojciechowski R., Średniowieczne consilia prawnicze, Przegląd Prawa i Administracji” 59, 2004, s. $169-176$.

Wojciechowski R., Zwiazek dydaktyki uniwersyteckiej i form literatury naukowej w XII i XIII wieku, „Prawo. Studia Historycznoprawne” 303, 2007. 